\title{
Modification of C2,3,23,28 Functional Groups on Asiatic Acid and Evaluation of Hepatoprotective Effects
}

\author{
Byeong-Seon Jeong, Young Choong Kim, ${ }^{\dagger}$ and Eung-Seok Lee \\ College of Pharmacy, Yeungnam Lniversity, Kyongsan 71 2-749, Korea. ${ }^{\circ}$ E-mail: eslee a. \\ ${ }^{\dagger}$ College of Phamacy, Seoth National Lniversitw, Seoul 151-7+2, Korea \\ Received April 11, 2007
}

\begin{abstract}
For the development of novel hepatoprotective agents. C2, C3, C23 and C28 functional groups on asiatic acid were modified. and the prepared compounds were evaluated for their hepatoprotective effects. Among the prepared compounds. 9.13 and 16 showed significant hepatoprotective activities against $\mathrm{CCl}_{4^{-}}$and galactosamine $(\mathrm{GaIN})$-induced hepatotoxicity. Especially compound 9 showed the most significant hepatoprotective effects against GaIN-induced hepatotoxicity $(66.4 \%$ protection at $50 \mu \mathrm{M})$ and moderate hepatoprotective activities against $\mathrm{CCl}_{-}$-induced hepatotoxiciț $(20.7 \%$ protection at $50 \mu \mathrm{M})$.
\end{abstract}

Key Words : Asiatic acid, Hepatoprotective effect, Structural modification, Hepatotoxicity

\section{Introduction}

Although acute and chronic hepatotoxicity has been recently increased. it has not been reported efficient dnigs for the treatment of hepatic disease without side effects. Triterpenoids such as ursane. oleanane and lupane have been reported to exhibit hepatoprotective effect ${ }^{1-6}$ Among them. ursolic acid and oleanoic acid which have ursane structures showed strong hepatoprotective activity. Asiatic acid whose structure is derived from ursane skeleton. is one of the triterpenoids isolated from Centella Asiatica. ${ }^{7}$ and has moderate hepatoprotective activity in itself. Asiatic acid can also be easily prepared from hydrolysis of asiaticoside. Previously we reported modifications of $\mathrm{C} 2$ functional group and C11. C28, C2.3.23 or C2.23.28 functional groups on asiatic acid and evaluation of their hepatoprotective effects. ${ }^{8-\bar{y}}$ From the previous structure-activity relationship studies. ${ }^{8-9}$ we found that simple modification of functional groups on $\mathrm{C} 2, \mathrm{C} 3, \mathrm{C} 23$ or $\mathrm{C} 28$ groups on asiatic acid greatly affected the hepatoprotective activities. It would be very interesting to prepare the modified derivatives on $\mathrm{C} 2, \mathrm{C} 3$. $\mathrm{C} 23$ and $\mathrm{C} 28$ functional groups on asiatic acid and evaluate hepatoprotective effects of the prepared compounds. In addition. structure-activity relationship studies of the prepared derivatives may provide valuable information for the development of novel hepatoprotective agents. In comnec- tion with previous studies. C2, C3, C23 and C28 functional groups on asiatic acid were modified and evaluated for their hepatoprotective effects.

\section{Experimental}

Material and methods. All reagents were purchased from Aldrich Chemical (www sigma-aldrich.com) and used without further purification. Unless otherwise indicated anhydrous solvent were distilled over $\mathrm{CaH}_{2}$ or sodium benzophenone ketyl prior to use. Thin-layer cluromatography (TLC) and columin chromatography were performed with Kieselgel $60 \mathrm{~F}_{25}$ (Merck) and silica gel Kieselgel 60. (230-400 mesh. Merck) respectively. Compounds containing aromatic ring were visualized on TLC plates with UV light. and compounds containing oxygen were visualized on TLC plates with $p$-anisaldehyde solution. Nuclear magnetic resonance (NMR) spectra were taken on a Bruker AMX $250 \mathrm{MHz}$ for ${ }^{\mathrm{j}} \mathrm{H}$ NMR and $62.5 \mathrm{MHz}$ for ${ }^{13} \mathrm{C}$ NMR and tetramethylsilane (TMS) was used as an internal standard. Chemical shifts $(\delta)$ were recorded in ppm, and coupling constants $(J)$ in $\mathrm{Hz}$. Melting points were determined in open capillary tubes on electrothermal 1A 9100 digital melting point apparatus and were uncorrected.

Methyl $2 \alpha, 3 \beta, 23$-trihydroxyurs-12-ene-28-oate (2). To a stirred solution of $1(2.6 \mathrm{~g} .5 .32 \mathrm{mmol})$ and anhydrous

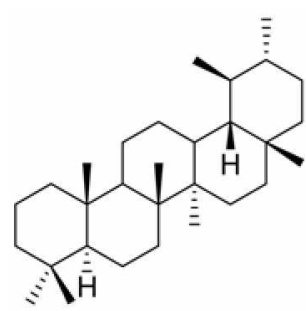

Ursane

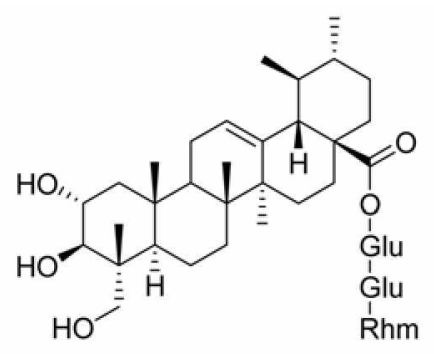

Asiaticoside

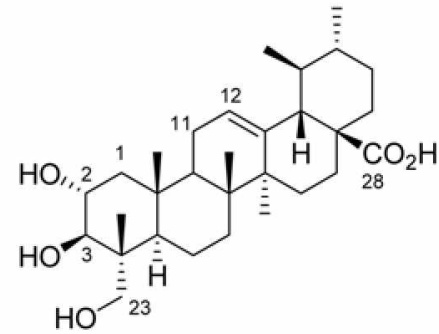

Asiatic acid

Figure 1. Structures of ursante, asiaticoside and asiatic acid. 
potassium carbonate $(1.84 \mathrm{~g}, 13.3 \mathrm{mmol})$ in dry DMF (20 $\mathrm{mL}$ ) was added methyl iodide $(0.66 \mathrm{~mL}, 10.64 \mathrm{~mm}$ ol $)$. The mixture was stirred at room temperature for $6 \mathrm{~h}$. The reaction mixture was diluted with ethyl acetate $(150 \mathrm{~mL})$ and washed with water $(50 \mathrm{~mL} \times 3)$ and saturated $\mathrm{NaCl}$ solution $(50 \mathrm{~mL})$. The organic phase was dried over anhydrous magnesium sulfate. Filtration and evaporation of solvent at reduced pressure gave light yellow solid, which was purified by silica gel chromatography with a gradient elution of $\mathrm{CH}_{2} \mathrm{Cl} / \mathrm{MeOH}(20: 1, \mathrm{v} v)$ to yield a white solid $(2.37 \mathrm{~g}$. $88.6 \%$ )

$\mathrm{TLC}\left(\mathrm{CH}_{2} \mathrm{Cl}_{2}: \mathrm{MeOH}=9: 1\right.$. v:v). $\mathrm{R}_{f}=0.3 .{ }^{1} \mathrm{H}$ NMR $(250$ $\left.\mathrm{MHz} \mathrm{CDCl}_{3}\right) \delta 5.25$ (br, $\mathrm{lH}$ ). 3.80-3.73 (m. IH). 3.69 (d. $J$ $=10.4 \mathrm{~Hz}, 1 \mathrm{H}) \cdot 3.60(\mathrm{~s}, 3 \mathrm{H}) \cdot 3.41 .3 .47$ (AB quartet. $J=9.2$ Hz, $2 \mathrm{H}) .2 .23(\mathrm{~d}, J=10.8 \mathrm{~Hz} . \mathrm{lH}) .0 .94(\mathrm{~d}, J=6.0 \mathrm{~Hz}, \mathrm{lH})$. 0.85 (d. $J=6.4 \mathrm{~Hz} .3 \mathrm{H}), 1.08 .1 .04 .0 .91,0.75$ (s. each $3 \mathrm{H}$ ). ${ }^{13} \mathrm{C}$ NMR $\left(62.5 \mathrm{MHz}, \mathrm{CDCl}_{3} . \mathrm{C} 12 . \mathrm{C} 13, \mathrm{C} 28\right.$ carbon only) $\delta$ 178.22. 138.14, 125.89

Methyl $2 \alpha, 3 \beta, 23$-trimethyloxyurs-12-ene-28-0ate (3). To the solution of $2(2.37 \mathrm{~g} .4 .7 \mathrm{mmol})$ in dry tetrahydrofuran $(50 \mathrm{~mL})$ was added $95 \%$ sodium hydride $(1.07 \mathrm{~g} .42 .7$ mmol) at $0^{\circ} \mathrm{C}$ and stirred for $20 \mathrm{~min}$ at $20^{\circ} \mathrm{C}$. To the nixture was added iodomethane $(1.76 \mathrm{~mL}, 28.27 \mathrm{mmmol})$ slowly and refluxed for $2 \mathrm{~h}$. The solvent was evaporated under reduced pressure to remove THF. The residue was diluted with ethyl acetate $(150 \mathrm{~mL})$ and washed with water $(50 \mathrm{~mL} \times 3)$ and saturated $\mathrm{NaCl}$ solution $(50 \mathrm{~mL})$. The organic phase was dried over anhydrous magnesium sulfate. Filtration and evaporation of solvent at reduced pressure gave light vellow solid, which was purified by silica gel chromatography with a gradient elution of $\mathrm{EtOAc} / n$-hexane $(1: 5, \mathrm{v}, \mathrm{v})$ to yield a white solid ( $2.44 \mathrm{~g} .95 .3 \%)$.

TLC (EtOAc: $n$-hexane $=1.5 . \quad \mathrm{v} v) . \mathrm{R}_{f}=0.25 .{ }^{1} \mathrm{H}$ NMR $\left(250 \mathrm{MHz} . \mathrm{CDCl}_{3}\right) \delta 5.25$ (t. $J=3.5 \mathrm{~Hz}, \mathrm{IH}$ ). $3.60,3.54$. $3.42,3.32$ (s. each $3 \mathrm{H}), 2.23(\mathrm{~d}, J=11.2 \mathrm{~Hz}, 1 \mathrm{H}) .0 .94(\mathrm{~d}, J=$ $6.0 \mathrm{~Hz} . \mathrm{IH}) .0 .85(\mathrm{~d}, J=6.4 \mathrm{~Hz}, 3 \mathrm{H}), 1.08,0.96,0.72,0.65$ (s. each $3 \mathrm{H}) .{ }^{13} \mathrm{C}$ NMR $\left(62.5 \mathrm{MHz}, \mathrm{CDCl}_{3}, \mathrm{Cl} 2 . \mathrm{Cl} 3, \mathrm{C} 28\right.$ carbon only) $\delta 178.49 .138 .63,125.75$.

Methyl 2 $\alpha, 3 \beta, 23$-trimethoxyurs-11-oxo-12-ene-28-0ate (4). A solution of 3 (1.5 g. $2.75 \mathrm{mmol}$ ) and $\mathrm{Na}_{2} \mathrm{Cr}_{2} \mathrm{O}_{7} \cdot 2 \mathrm{H}_{2} \mathrm{O}$ (2.05 g. $6.88 \mathrm{mmol}$ ) in $75 \mathrm{~mL}$ of acetic acid was refluxed for $5 \mathrm{~h}$. The mixture was cooled to $20^{\circ} \mathrm{C}$, neutralized with saturated $\mathrm{NaHCO}_{3}$ to $\mathrm{pH} 7-8$. diluted with ethyl acetate $(150$ $\mathrm{mL}$ ) and washed with water $(50 \mathrm{~mL} \times 3)$, and saturated $\mathrm{NaCl}$ solution $(50 \mathrm{~mL})$. The organic phase was dried over anhydrous magnesium sulfate. Filtration and evaporation of solvent at reduced pressure gave light yellow solid. which was purified by silica gel chromatography with a gradient elution of EtOAc/n-hexane $(1.5, \mathrm{v} v)$ to yield a white solid $(1.1 \mathrm{~g}$. $71.6 \%)$.

TLC (EtOAc: $n$-hexane $=1: 5 . \quad \mathrm{v}) . \mathrm{R}_{f}=0.15 .{ }^{1} \mathrm{H}$ NMR $\left(250 \mathrm{MHz}, \mathrm{CDCl}_{3}\right) \delta 5.61$ (s, 1H). 3.61. 3.54, 3.43.3.31 (s. each $3 \mathrm{H}) .3 .23$ (dd. $J=12.7 .4 .5 \mathrm{~Hz}, \mathrm{lH}) .3 .14$ (d. $J=9.4 \mathrm{~Hz}$. lH). $3.08($ d. $J=9.3 \mathrm{~Hz} .1 \mathrm{H}) .3 .05(\mathrm{~d} J=8.8 \mathrm{~Hz} .1 \mathrm{H}) .2 .42$ (d. $J=11.2 \mathrm{~Hz}, 1 \mathrm{H}$ ). 2.37 (s. $1 \mathrm{H}$ ). 0.97 (d. $J=5.8 \mathrm{~Hz} .3 \mathrm{H}$ ). 0.87 (d. $J=6.6 \mathrm{~Hz} .3 \mathrm{H}), 1.30 .1 .16 .0 .89,0.67$ (s. each $3 \mathrm{H}$ ). ${ }^{13} \mathrm{C}$ NMR $\left(62.5 \mathrm{MHz}, \mathrm{CDCl}_{3,}, \mathrm{C} 11 . \mathrm{Cl} 2, \mathrm{C} 13 . \mathrm{C} 28\right.$ carbon only) $\delta 200.08 .177 .62 .163 .43,131.00$.

Methyl $2 \alpha$-acetyloxy-3 $\beta, 23$-isopropylidenedioxyurs-12ene-28-oate (6). To a stirred solution of 5 ( $2.8 \mathrm{~g}, 5.16$ mmol) $)^{8}$ in THF $(50 \mathrm{~mL})$ was added 4-dimethylaminopyridine $\left(20 \mathrm{mg}\right.$ ) at $20^{\circ} \mathrm{C}$. After stirring for $30 \mathrm{~min}$. acetic anhydride $(1.04 \mathrm{~mL}, 10.32 \mathrm{mmol}$ ) was added. and the mixture was stirred for $2 \mathrm{~h}$ at $20^{\circ} \mathrm{C}$. The solvent was evaporated under reduced pressure to remove THF. The residue was purified by silica gel chromatography with a gradient elution of EtOAc/n-hexane (1:5. viv) to yield a white solid $(2.5 \mathrm{~g} .83 \%)$.

TLC $($ EtOAc $: n$-hexane $=1.5 . \mathrm{v} v) . \mathrm{R}_{f}=0.2 .{ }^{1} \mathrm{H}$ NMR $(250$ $\left.\mathrm{MHz}, \mathrm{CDCl}_{3}\right) \delta 5.24(\mathrm{br}, J=3.4 \mathrm{~Hz} . \mathrm{lH}) .5 .00(\mathrm{~m}, \mathrm{lH}) .3 .60$ $(\mathrm{s}, 3 \mathrm{H}$ ). 3.53 (d. $J=10.7 \mathrm{~Hz} . \mathrm{lH}$ ). $3.54,3.48$ (AB quartet, $J=$ $10.3 \mathrm{~Hz} .2 \mathrm{H}$ ). 2.23 (d. $J=12.2 \mathrm{~Hz} . \mathrm{lH}$ ), $2.0 \mathrm{l}$ (s. $3 \mathrm{H}$ ), 0.94 (d. $J=6.0 \mathrm{~Hz}, 3 \mathrm{H}), 0.85(\mathrm{~d} . J=6.4 \mathrm{~Hz}, 3 \mathrm{H}), 1.43 .1 .41 .1 .12$, 1.09. $1.08 .0 .73(\mathrm{~s}$, each $3 \mathrm{H}){ }^{13} \mathrm{C}$ NMR $(62.5 \mathrm{MHz}, \mathrm{CDCl}$, $\mathrm{C} 12 . \mathrm{Cl} 3, \mathrm{C} 28$ carbon only) $\delta 178.87,138.14,125.66$.

Methyl $2 \alpha$-acetyloxy-3 $\beta, 23$-dihydroxyurs-12-ene-28-0ate (7). To the solution of $6(9.2 \mathrm{~g} .15 .7 \mathrm{mmol})$ in THF $(80 \mathrm{~mL})$ was added $1 \mathrm{M} \mathrm{HCl}(20 \mathrm{~mL})$ at $20^{\circ} \mathrm{C}$ and stirred $3 \mathrm{~h}$. The solvent was evaporated under reduced pressure to remove THF. The residue was diluted with ethyl acetate $(300 \mathrm{~mL})$ and washed with water $(100 \mathrm{~mL} \times 3)$ and saturated $\mathrm{NaCl}$ solution $(80 \mathrm{~mL})$. The organic phase was dried over anlydrous magnesium sulfate. Filtration and evaporation of solvent at reduced pressure gave light yellow solid, which was purified by silica gel chromatography with a gradient elution of EtOAc/n-hexane $(1: 1, \mathrm{vv})$ to yield a white solid $(6.5 \mathrm{~g}$. $76 \%$ ).

TLC (EtOAc: -hexane $=1: 1$, v.v), $\mathrm{R}_{f}=0.15,{ }^{1} \mathrm{H}$ NMR $\left(250 \mathrm{MHz} . \mathrm{CDCl}_{3}\right) \delta 5.24$ (t. $\left.J=3.6 \mathrm{~Hz} . \mathrm{lH}\right), 5.03-4.97(\mathrm{~m}, \mathrm{l}$ H), $3.60(\mathrm{~s}, 3 \mathrm{H}), 2.23(\mathrm{~d} . J=11.6 \mathrm{~Hz} . \mathrm{lH}), 2.02(\mathrm{~s}, 3 \mathrm{H}), 1.08$ (d. $J=6 \mathrm{~Hz}, 3 \mathrm{H}) .0 .84($ d. $J=6.4 \mathrm{~Hz} .3 \mathrm{H}), 1.09,1.07,0.90$. 0.75 (s. each $3 \mathrm{H}),{ }^{13} \mathrm{C}$ NMR $(62.5 \mathrm{MHz}, \mathrm{CDCl}, \mathrm{Cl} 2 . \mathrm{Cl} 3$, C28 carbon only) $\delta 177.88,139.11 .125 .82$.

Methyl $2 \alpha$-acetyloxy-3 $\beta$ 23-hydroxyurs-12-ene-23-al-28oate (8). A solution of pyridinium dichromate (688 $\mathrm{mg} .1 .83$ mmol) and $7(500 \mathrm{mg} .0 .914 \mathrm{mmol})$ in dry $\mathrm{CH}_{2} \mathrm{Cl}_{2}(20 \mathrm{~mL})$ was stirred for $3 \mathrm{~h}$ at $20^{\circ} \mathrm{C}$. The mixture was diluted with ethyl acetate $(100 \mathrm{~mL})$ and filtered to remove precipitate and washed with water $(30 \mathrm{~mL} \times 3)$ and saturated $\mathrm{NaCl}$ solution $(30 \mathrm{~mL})$. The organic phase was dried over anhydrous magnesium sulfate. Filtration and evaporation of solvent at reduced pressure gave a light yellow solid, which was purified by silica gel cluromatography with a gradient elution of $\mathrm{EtOAc} / n$-hexane (1:2. v:v) to yield a white solid (228 mg. $46 \%$ ).

TLC (EtOAc: $n$-hexane $=1: 2, \mathrm{v} v), \mathrm{R}_{f}=0.20 .{ }^{\mathrm{l}} \mathrm{H}$ NMR $(250$ MHz. $\left.\mathrm{CDCl}_{3}\right) \delta 9.40$ (s. $\mathrm{lH}$ ), 5.25 (t. $J=4 \mathrm{~Hz} . \mathrm{lH}$ ), 5.05-4.99 $(\mathrm{m}, \mathrm{lH}), 3.60(\mathrm{~s}, 3 \mathrm{H}), 2.24(\mathrm{~d} . J=12 \mathrm{~Hz}, 1 \mathrm{H}), 2.08(\mathrm{~s}, 3 \mathrm{H})$, $0.94(\mathrm{~d} . J=6 \mathrm{~Hz}, 3 \mathrm{H}) .0 .85(\mathrm{~d} J=6.4 \mathrm{~Hz}, 3 \mathrm{H}), 1.29 .1 .11,1.09$. 0.75 (s. each $3 \mathrm{H}),{ }^{13} \mathrm{C} \mathrm{NMR}\left(62.5 \mathrm{MHz}, \mathrm{CDCl}_{3}, \mathrm{Cl} 2 . \mathrm{Cl} 3\right.$, C23. C28 carbon only) $\delta 205.84$. 177.26, 137.55. 126.39.

Methyl $2 \alpha$-acetyloxyurs-3-one-12-ene-23-al-28-0ate (9). A solution of pyridinium dichromate $(290 \mathrm{mg} .0 .77 \mathrm{mmol})$ and 8 (140 mg. $0.26 \mathrm{mmol})$ in dry $\mathrm{CH}_{2} \mathrm{Cl}_{2}(15 \mathrm{~mL})$ was 
stirred $3 \mathrm{~h}$ at $20^{\circ} \mathrm{C}$ and refluxed for $2 \mathrm{~h}$. The mixture was diluted with ethyl acetate $(60 \mathrm{~mL})$ and filtered to remove precipitate and washed with water $(20 \mathrm{~mL} \times 3)$ and saturated $\mathrm{NaCl}$ solution $(20 \mathrm{~mL})$. The organic phase was dried over anhydrous magnesium sulfate. Filtration and evaporation of solvent at reduced pressure gave light yellow solid. which was purified by silica gel chromatography with a gradient elution of EtOAc/n-hexane (1:4. viv) to yield a white solid (59 $\mathrm{mg}, 42 \%$ ).

TLC (EtOAc:n-hexane =1:4. v.v). $\mathrm{R}_{f}=0.2 .{ }^{1} \mathrm{H}$ NMR $(250$ $\left.\mathrm{MHz}, \mathrm{CDCl}_{3}\right) \delta 9.43$ (s. $\left.\mathrm{lH}\right), 5.55-5.47(\mathrm{~m}, \mathrm{lH}), 5.27$ (br. $\mathrm{lH}$ ). 3.61 (s. $3 \mathrm{H}), 2.25$ (d. $J=11 \mathrm{~Hz} .1 \mathrm{H}), 2.13(\mathrm{~s}, \mathrm{H}) .0 .94$ (d. $J=$ $6.4 \mathrm{~Hz} .3 \mathrm{H}) .0 .86(\mathrm{~d}, J=6.4 \mathrm{~Hz}, 3 \mathrm{H}), 1.34,1.33,1.10,0.82$ (s, each $3 \mathrm{H}),{ }^{13} \mathrm{C}$ NMR $\left(62.5 \mathrm{MHz}, \mathrm{CDCl}_{3}, \mathrm{C} 3, \mathrm{Cl} 2 . \mathrm{Cl} 3, \mathrm{C} 23\right.$, C 28 carbon only) $\delta 210.36,200.33,177.98 .138 .27,124.89$

Methyl $2 \alpha$-methyloxy-3 $\beta, 23$-dihydroxyurs-12-ene-28oate (10). To the solution of 5 ( 2 g. $3.68 \mathrm{nmol})$ in dry THF $(20 \mathrm{~mL})$ was added $95 \%$ sodium hydride $(0.31 \mathrm{~g} .12 .36$ mmol) at $0{ }^{\circ} \mathrm{C}$ and stirred for $20 \mathrm{~min}$ at $20^{\circ} \mathrm{C}$. To the mixture was added methyl iodide $(6 \mathrm{~mL})$ slowly and refluxed for $2 \mathrm{~h}$. The reaction was quenched with a drop of aqueous $\mathrm{I} \mathrm{M} \mathrm{HCl}$. The mixture was concentrated under reduced pressure. To the residue was added aqueous $1 \mathrm{M} \mathrm{HCl}(20 \mathrm{~mL})$ and THF $\left(30 \mathrm{~mL}\right.$ ) at $20^{\circ} \mathrm{C}$ and stirred $2 \mathrm{~h}$. The solvent was evaporated under reduced pressure to remove THF. The residue was diluted with ethyl acetate $(150 \mathrm{~mL})$ and washed with water $(50 \mathrm{~mL} \times 3)$ and saturated $\mathrm{NaCl}$ solution $(50 \mathrm{~mL})$. The organic phase was dried over anhydrous magnesium sulfate. Filtration and evaporation of solvent at reduced pressure gave light yellow solid. which was purified by silica gel chromatography with a gradient elution of EtOAc/n-hexane $(1: 1, \mathrm{viv})$ to yield a white solid $(1.4 \mathrm{~g} .78 .3 \%)$.

TLC (EtOAc: $n$-hexane $=1: 1 . \quad$ vis), $R_{f}=0.15 .{ }^{1} \mathrm{H}$ NMR $\left(250 \mathrm{MHz}, \mathrm{CDCl}_{3}\right) \delta 5.26$ (t. $\left.J=3.6 \mathrm{~Hz} . \mathrm{lH}\right), 3.32-3.24$ (m. lH), $2.24(\mathrm{~d} . J=11.2 \mathrm{~Hz}, 3 \mathrm{H}), 0.94(\mathrm{~d} . J=5.8 \mathrm{~Hz}, 3 \mathrm{H}) .0 .85$ (d. $J=6.4 \mathrm{~Hz} .3 \mathrm{H}$ ). $3.60 .3 .39,1.07 .1 .03 .0 .92,0.75$ (s, each $3 \mathrm{H}),{ }^{13} \mathrm{C}$ NMR $\left(62.5 \mathrm{MHz} . \mathrm{CDCl}_{3}, \mathrm{Cl} 2 . \mathrm{Cl} 3, \mathrm{C} 28\right.$ carbon only) $\delta 178.56,138.63 .125 .27$.

Methyl $2 \alpha$-methyloxy-3 $\beta, 23$-diacetyloxyurs-12-ene-28oate (11). To a stirred solution of 10 (400 $\mathrm{mg} .0 .77 \mathrm{mmol})$ in $\mathrm{CH}_{2} \mathrm{Cl}_{2}(10 \mathrm{~mL})$ was added t-dimethylaninopyridine $(20$ $\mathrm{mg}$ ) at $20^{\circ} \mathrm{C}$. After stirring for $30 \mathrm{~min}$, acetic anhydride $(0.73 \mathrm{~mL}, 7.7 \mathrm{mmol})$ was added, and the mixture was stirred for $2 \mathrm{~h}$ at $20^{\circ} \mathrm{C}$. The solvent was evaporated under reduced pressure to remove $\mathrm{CH}_{2} \mathrm{Cl}_{2}$. The residue was diluted with ethyl acetate $(50 \mathrm{~mL})$ and washed with water $(20 \mathrm{~mL} \times 2)$ and saturated $\mathrm{NaCl}$ solution $(30 \mathrm{~mL})$. The organic phase was dried over anhydrous magnesium sulfate. Filtration and evaporation of solvent at reduced pressure gave light yellow solid. which was purified by silica gel chromatography with a gradient elution of EtOAc/n-hexane $(1: 4, \mathrm{vv})$ to yield a white solid (250 mg. $57.0 \%$ ).

TLC (EtOAc: $n$-hexane $=1: 2 . \quad \vee \mathrm{v}), \mathrm{R}_{f}=0.30 .{ }^{1} \mathrm{H}$ NMR $\left(250 \mathrm{MHz} . \mathrm{CDCl}_{3}\right) \delta 5.27$ (br. $\mathrm{lH}$ ). 5.06 (d. $J=10.1$. $\mathrm{HH}$ ). $3.86(\mathrm{~d}, J=11.8 \mathrm{~Hz} .1 \mathrm{H}) .3 .65(\mathrm{~d} . J=11.6 \mathrm{~Hz}, 1 \mathrm{H}), 3.61$ (s. $3 \mathrm{H}$ ). 3.30 (s. $3 \mathrm{H}$ ). 2.29 (s. $3 \mathrm{H}$ ). 2.25 (d. $J=12.5 \mathrm{~Hz} .1 \mathrm{H}$ ). $2.08(\mathrm{~s} .3 \mathrm{H}), 1.08,1.03 .0 .83 .0 .75(\mathrm{~s}$ each $3 \mathrm{H}), 0.94(\mathrm{~d} . J=$
$6.0 \mathrm{~Hz} .3 \mathrm{H}), 0.86(\mathrm{~d} . J=6.5 \mathrm{~Hz}, 3 \mathrm{H}) .{ }^{13} \mathrm{C}$ NMR $(62.5 \mathrm{MHz}$, $\mathrm{CDCl}_{3} . \mathrm{C}_{3} . \mathrm{Cl} 2 . \mathrm{Cl} 3 . \mathrm{C} 23, \mathrm{C} 28$ carbon only) $\delta 178.47$, 171.35, 167.04. 138.78. 125.43.

Methyl $2 \alpha$-methyloxy-3 $\beta$-hydroxyurs-12-ene-23-al-28oate (12). A solution of pyridinium dichromate $(728 \mathrm{mg}$, $1.94 \mathrm{mmol})$ and $10(500 \mathrm{mg})$ in dry $\mathrm{CH}_{2} \mathrm{Cl}_{2}(20 \mathrm{~mL})$ was stirred $3 \mathrm{~h}$ at $20^{\circ} \mathrm{C}$. The mixture was diluted with etlyy acetate $(50 \mathrm{~mL})$ and was filtered to remove precipitate and washed with water $(20 \mathrm{~mL} \times 2)$ and saturated $\mathrm{NaCl}$ solution $(30 \mathrm{~mL})$. The organic phase was dried over anlydrous magnesium sulfate. Filtration and evaporation of solvent at reduced pressure gave light yellow solid. which was purified by silica gel cluromatography with a gradient elution of EtOAc/n-hexane $(1: 4, v \mathrm{v})$ to yield a white solid $(220 \mathrm{mg}$. $44.1 \%)$.

TLC (EtOAc:n-hexane $=1: 4, v v), \mathrm{R}_{f}=0.15 .{ }^{1} \mathrm{H}$ NMR $\left(250 \mathrm{MHz}, \mathrm{CDCl}_{3}\right) \delta 9.35(\mathrm{~s} . \mathrm{HH}), 5.27(\mathrm{t}, J=3.5 \mathrm{~Hz} . \mathrm{lH})$, $3.6 \mathrm{l}(\mathrm{s}, 3 \mathrm{H}) .3 .60(\mathrm{~d}, J=9.4 \mathrm{~Hz} . \mathrm{lH}), 3.4(\mathrm{~s}, 3 \mathrm{H}) .3 .34(\mathrm{~m}$, 1H). $2.24(\mathrm{~d}, J=11.3 \mathrm{~Hz}, 1 \mathrm{H}), 1.11,1.09,1.04 .0 .75(\mathrm{~s}, 3 \mathrm{H})$, 0.94 (d. $J=6.0 \mathrm{~Hz}, 3 \mathrm{H}) .0 .85$ (d. $J=6.4 \mathrm{~Hz} .3 \mathrm{H}$ ). ${ }^{13} \mathrm{C}$ NMR (62.5 MHz. $\mathrm{CDCl}_{3} . \mathrm{Cl} 2, \mathrm{Cl} 13 . \mathrm{C} 23 . \mathrm{C} 28$ carbon only) $\delta$ $205.85,178.42$. 138.85. 125.27.

Methyl $2 \alpha$-methyloxyurs-3-one-12-ene-23-al-28-oate (13). A solution of pyridinium dicluromate $(395 \mathrm{mg} .1 .05$ mumol) and 12 (180 mg. $0.35 \mathrm{mmol})$ in dry $\mathrm{CH}_{2} \mathrm{Cl}_{2}(20 \mathrm{~mL})$ was stirred $3 \mathrm{~h}$ at $20^{\circ} \mathrm{C}$ and refluxed for $2 \mathrm{~h}$. The mixture was diluted with etlyl acetate $(50 \mathrm{~mL})$ and filtered to remove precipitate and washed with water $(20 \mathrm{~mL} \times 2)$ and saturated $\mathrm{NaCl}$ solution $(30 \mathrm{~mL}$ ). The organic phase was dried over anlydrous magnesium sulfate. Filtration and evaporation of solvent at reduced pressure gave light yellow solid. which was purified by silica gel chromatography with a gradient elution of EtOAc/n-hexane $(1: 5, \mathrm{vr})$ to yield a white solid (100 mg. 55.7\%).

TLC $($ EtOAc: 7 -hexane $=1.5 . \mathrm{vv}) . \mathrm{R}_{f}=0.23 .{ }^{1} \mathrm{H}$ NMR $\left(250 \mathrm{MHz}, \mathrm{CDCl}_{3}\right) \delta 9.42(\mathrm{~s}, 1 \mathrm{H}), 5.28(\mathrm{t}, J=3.5 \mathrm{~Hz} . \mathrm{lH})$, $3.93(\mathrm{dd}, J=10.3,6.6 \mathrm{~Hz} .1 \mathrm{H}), 3.61(\mathrm{~s}, 3 \mathrm{H}) .3 .39$ (s. $3 \mathrm{H})$, 2.36 (dd. $J=13.2 .6 .6 \mathrm{~Hz} .1 \mathrm{H}) .2 .26(\mathrm{~d} . J=11.3 \mathrm{~Hz} .1 \mathrm{H}$ ). 1.29. 1.21. 1.11 .0 .79 (s. each $3 \mathrm{H}$ ). 0.94 (d. $J=6.0 \mathrm{~Hz}, 3 \mathrm{H}$ ). $0.86(\mathrm{~d} J=6.4 \mathrm{~Hz}, 3 \mathrm{H}),{ }^{13} \mathrm{C}$ NMR $\left(62.5 \mathrm{MHz} . \mathrm{CDCl}_{3} . \mathrm{C} 3\right.$, C12. C13, C23. C28 carbon only) d 210.02. 200.06, 178.39 . 138.94. 125.09

Methyl $2 \alpha$-benzyloxy-3 $\beta$,23-dihydroxyurs-12-ene-28oate (15). To the solution of $14(1.36 \mathrm{~g} .2 .15 \mathrm{mmol})^{8}$ in THF $(50 \mathrm{~mL})$ was added aqueous $1 \mathrm{M} \mathrm{HCl}(10 \mathrm{~mL})$ and stirred for $2 \mathrm{~h}$ at $20^{\circ} \mathrm{C}$. The solvent was evaporated under reduced pressure to remove THF. The residue was diluted with ethyl acetate $(150 \mathrm{~mL})$ and washed with water $(50 \mathrm{~mL} \times 2)$ and saturated $\mathrm{NaCl}$ solution $(60 \mathrm{~mL})$. The organic phase was dried over anlydrous magnesium sulfate. Filtration and evaporation of solvent at reduced pressure gave light yellow solid. which was purified by silica gel chromatography with a gradient elution of EtOAc/n-hexane (1:2, vv) to yield a white solid (1.15 g. 90.2\%).

TLC $($ EtOAc $n$-hexane $=1: 2, \mathrm{vv}) . \mathrm{R}_{f}=0.21 .{ }^{1} \mathrm{H}$ NMR $\left(250 \mathrm{MHz} . \mathrm{CDCl}_{3}\right.$ ) $\delta 7.38-7.28$ (m, phenyl $5 \mathrm{H}$ ), 5.26 (br. 1H). 4.68. 4.44 (AB quartet, $J=11.2 \mathrm{~Hz}, 2 \mathrm{H}) .3 .61(\mathrm{~s} .3 \mathrm{H})$, 
3.66-3.48 (m, 3H), $3.39(\mathrm{~d}, J=10.7 \mathrm{~Hz} .1 \mathrm{H}) .2 .93(\mathrm{~s}, \mathrm{H})$. $2.24(\mathrm{~d}, J=11.3 \mathrm{~Hz} .1 \mathrm{H}), 1.08,1.02 .0 .88 .0 .75$ (s, each $3 \mathrm{H}$ ). $0.94(\mathrm{~d}, J=6.0 \mathrm{~Hz}, 3 \mathrm{H}) .0 .86(\mathrm{~d} . J=6.6 \mathrm{~Hz} .3 \mathrm{H}){ }^{13} \mathrm{C}$ NMR $\left(62.5 \mathrm{MHz}, \mathrm{CDCl}_{3} . \mathrm{C} 12, \mathrm{Cl}, \mathrm{C} 28\right.$ carbon only) $\delta 178.26$. 138.43. 125.27 .

Methyl $2 \alpha$-benzyloxy-3 $\beta, 23$-diacetyloxyurs-12-ene-28oate (16). To a stirred solution of $15(600 \mathrm{mg}, 1.01 \mathrm{mmol})$ in THF $(50 \mathrm{~mL})$ was added 4-dimetly laminopyridine $(20 \mathrm{mg})$ at $20^{\circ} \mathrm{C}$. After stirring for $30 \mathrm{~min}$, acetic anhydride $(0.57$ $\mathrm{mL}$. $6.07 \mathrm{mumol}$ ) was added, and the mixture was stirred for $2 \mathrm{~h}$ at $20^{\circ} \mathrm{C}$. The solvent was evaporated under reduced pressure to renove THF. The residue was diluted with ethyl acetate $(100 \mathrm{~mL})$ and washed with water $(30 \mathrm{~mL} \times 2)$ and saturated $\mathrm{NaCl}$ solution $(30 \mathrm{~mL})$. The organic phase was dried over anhydrous magnesiun sulfate. Filtration and evaporation of solvent at reduced pressure gave light yellow solid, which was purified by silica gel chronatography with a gradient elution of $\mathrm{EtOAc} / n$-hexane $(1: 4 . \mathrm{v}: \mathrm{v})$ to yield a white solid (550 mg. 65.8\%).

TLC (EtOAc: $n$-hexane $=1: 4, v v), R_{f}=0.25,{ }^{1} \mathrm{H}$ NMR (250 $\mathrm{MHz}, \mathrm{CDCl}_{3}$ ) $\delta 7.35-7.25$ (m. phenyl $5 \mathrm{H}$ ), 5.27 (br. lH), $5.08(\mathrm{~d}, J=10.0 \mathrm{~Hz}, \mathrm{lH}) .4 .62(\mathrm{~d} . J=11.9 \mathrm{~Hz}, \mathrm{lH})$. $4.45(\mathrm{~d} . J=11.9 \mathrm{~Hz} .1 \mathrm{H}), 3.84(\mathrm{~d} . J=11.7 \mathrm{~Hz}, 1 \mathrm{H}), 3.66(\mathrm{~m}$. $1 \mathrm{H}), 3.6 \mathrm{l}(\mathrm{s}, 3 \mathrm{H}) .3 .56(\mathrm{~d}, J=11.8 \mathrm{~Hz} .1 \mathrm{H}), 2.24$ (d. $J=11.3$ $\mathrm{Hz}, \mathrm{IH}), 2.16$ (dd, $J=12.5 .4 .7 \mathrm{~Hz} . \mathrm{lH}), 2.08,2.02$ (s, each $3 \mathrm{H}), 1.07,1.01,0.82,0.75(\mathrm{~s}$, each $3 \mathrm{H}) .0 .94(\mathrm{~d} . J=6.0 \mathrm{~Hz}$. $3 \mathrm{H}), 0.86($ d. $J=6.4 \mathrm{~Hz} .3 \mathrm{H}) .{ }^{13} \mathrm{C}$ NMR $\left(62.5 \mathrm{MHz} . \mathrm{CDCl}_{3}\right.$. $\mathrm{C} 3, \mathrm{Cl} 2, \mathrm{C} 13 . \mathrm{C} 23 . \mathrm{C} 28$. phenyl carbon only) $\delta 178.03$. 171.06. 170.50, 138.69. 138.29. 128.24, 127.33. 127.17. 125.04.

Primary cell cultured rat hepatocytes assay. Rat hepatocytes were prepared from male Wistar rats by a collagenase perfusion teclinique of Berry and Friend with minor modification. ${ }^{1 i}$ After $24 \mathrm{~h}$, the isolated rat hepatocytes were plated. the cultured cells were exposed to a culture containing $5 \mathrm{mM}$ of chloroform or glucosamine either with, or without the prepared compounds along with asiatic acid and silymarin. After $1.5 \mathrm{~h}$. the activities of glutamic pynuvic transaminase (GPT) released into the culture medium were determined by the method of Reitman-Frankel. ${ }^{11}$ All data are expressed as the mean $\pm \mathrm{SD}$. The evaluation of statistical significance was determined by "the one-way ANOVA" using a computerized statistical package. The data were considered to be statistically significant if the probability had a value of 0.05 or less.

\section{Results and Discussion}

Chemistry. Methylation of asiatic acid (1) with metlyyl iodide in the presence of $\mathrm{K}_{2} \mathrm{CO}_{3}$ gave methyl ester intermediate 2 in $88.6 \%$ yield. Further methylation of 2 with methyl iodide in the presence of $\mathrm{NaH}$ afforded methoxy intermediate 3 in $95.3 \%$ yield, which was converted to $\alpha \beta$ unsaturated ketone + in $71.6 \%$ yield by the oxidation with $\mathrm{Na}_{2} \mathrm{Cr}_{2} \mathrm{O}_{7}$ in the presence of acetic acid. ${ }^{12}$ (Scheme I)

For the preparation of C2-acetoxy, C3-oxo. C23-aldelyyde and C28-methyl substituted asiatate 9 , acetylation of $5^{8}$ with acetic anhydride gave 6 in $83 \%$ yield. which was converted to diol 7 in $76 \%$ yield by the deprotection with aqueous $1 \mathrm{M}$ $\mathrm{HCl}$. Concurrent oxidation of the diol in 7 would be expected directly to give $\beta$-keto aldehydes 9 which could provide various synthetic routes to modify to other compounds. But treatment of 7 with pyridinium dichromate (PDC) or pyridinium chlorochromate (PCC) gave C23-aldehyde 8 in $46 \%$ yield. which was converted to $\beta$ keto aldehyde 9 in $42 \%$ yield by the further oxidation with PDC (Scheme 2).

For the preparation of $3 \beta, 23$-diacetoxy substituted compound 11, methyl ester $\mathbf{5}$ was treated with $\mathrm{MeI}$ and $\mathrm{NaH}$ in THF, followed by deprotection with aqueous $1 \mathrm{M} \mathrm{HCl}$ to form diol compound 10 in $78.3 \%$ yield. which was treated with acetic anhydride in the presence of DMAP to afford 11 in $57.0 \%$ yield (Scheme 3 ).

With the similar procedure described in Scheme 2. compound 13 containing $2 \alpha$-methoxy, 3-oxo and 23-aldehyde functional groups was obtained in $24.6 \%$ overall yield (Scheme 4).
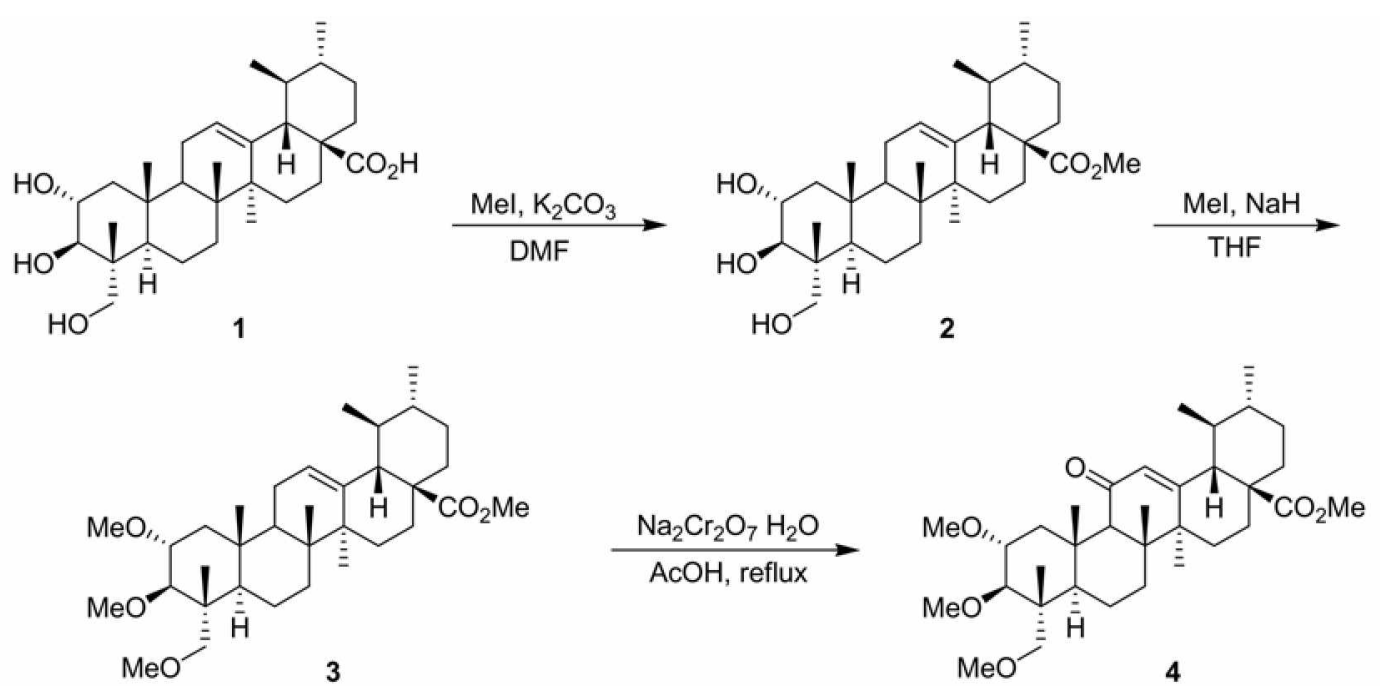

Scheme 1. Synthesis of C2,3,23-trimethoxy and C28-methyl substituted asiatic acid. 


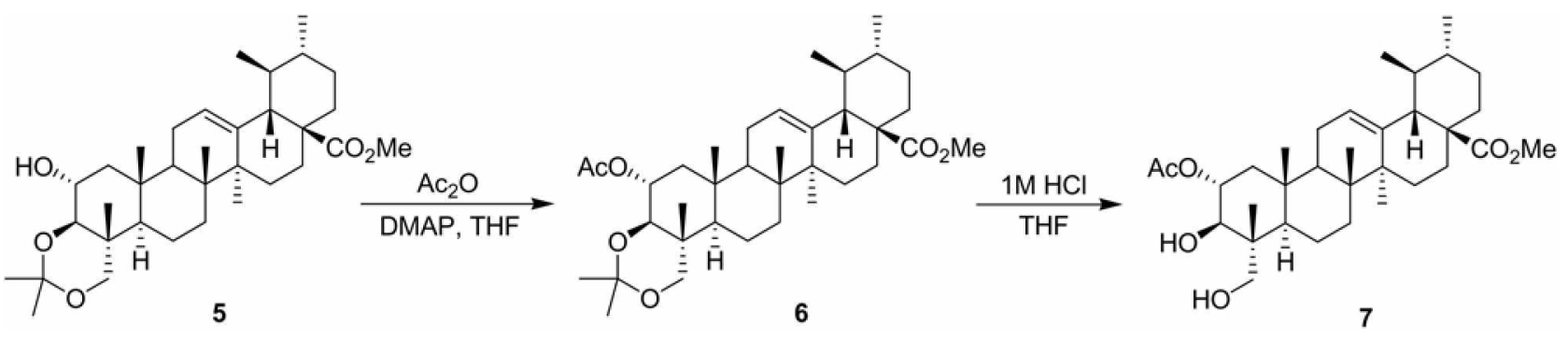

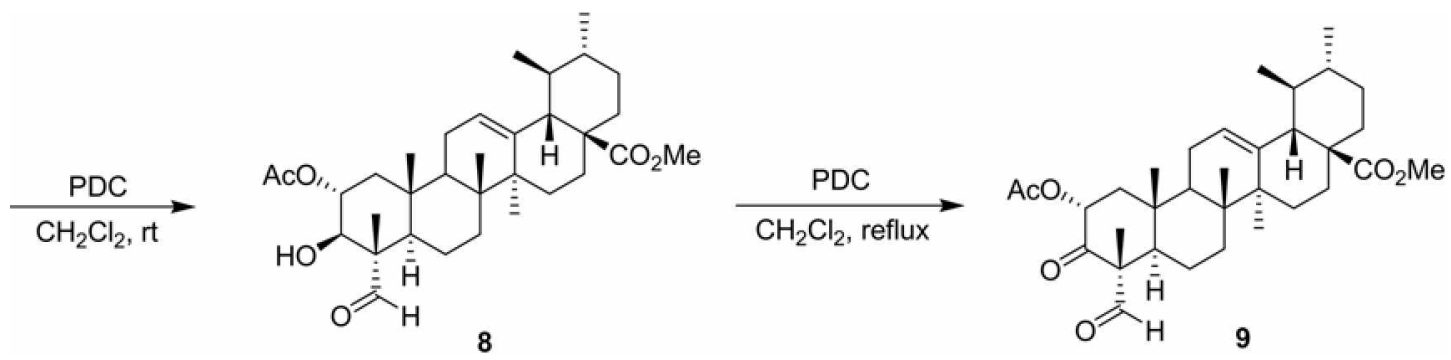

Scheme 2. Synthesis of C2-acetoxy, C3-0xo, C23-aldehyde and C28-methyl substituted asiatic acid.

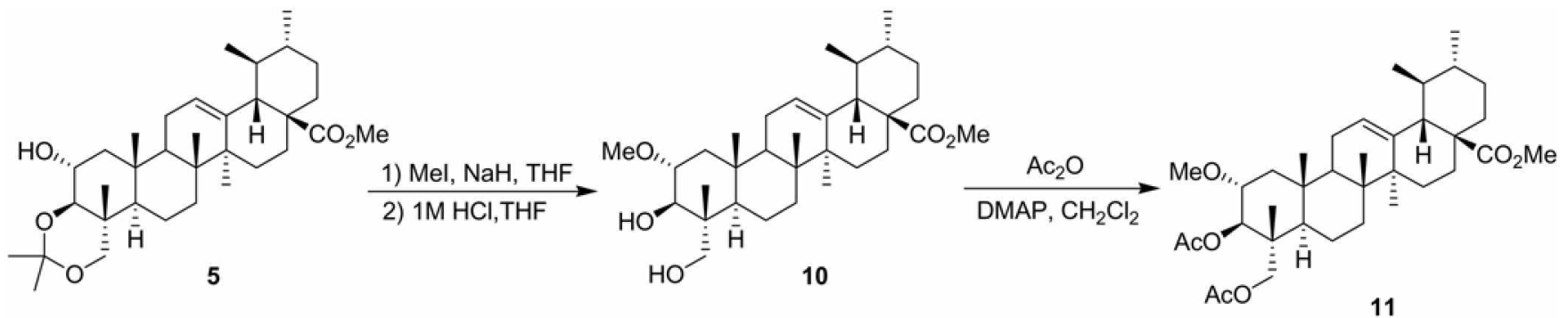

Scheme 3. Synthesis of $\mathrm{C} 2$-methoxy, C3,23-diacetoxy and C28-methyl substituted asiatic acid.

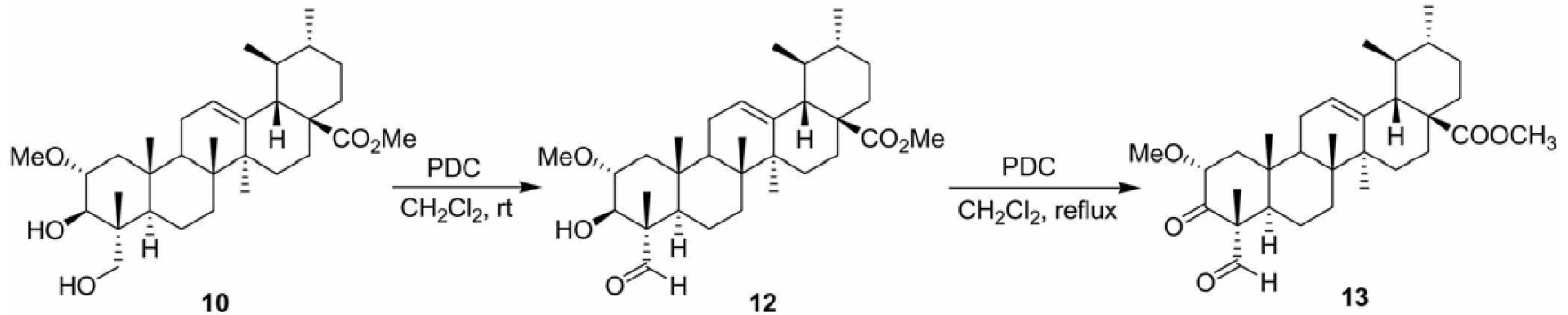

Scheme 4. Synthesis of C2-methoxy, C3-0xo, C23-aldehyde and C28-methyl substituted asiatic acid.

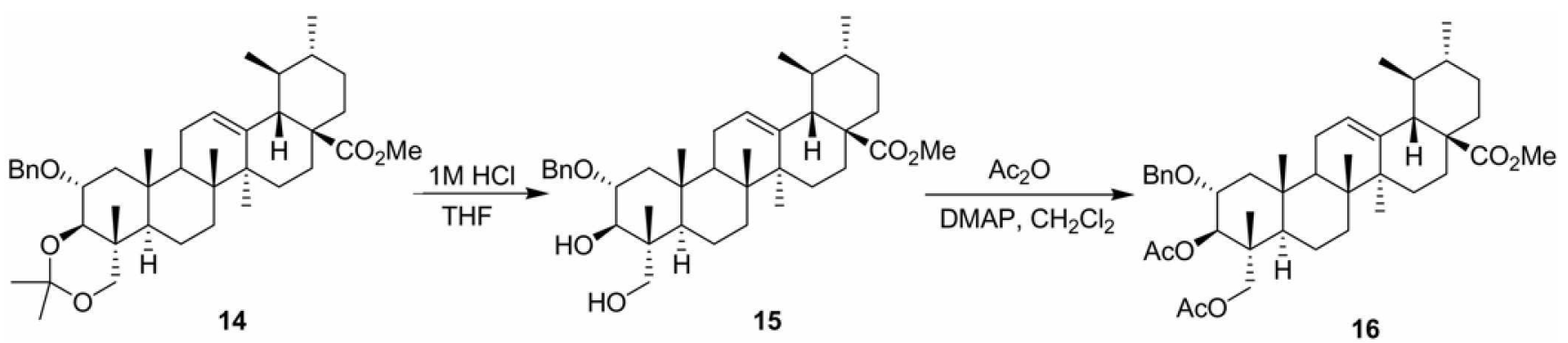

Scheme 5. Synthesis of C2-benzy loxy, C3,23-diacetoxy and C28-methyl substituted asiatic acid.

For the preparation of $3 \beta, 23$-diacetyloxy substituted compound 16, $14^{8}$ was reacted with aqueous $1 \mathrm{M} \mathrm{HCl}$ in THF to give diol compound $\mathbf{1 5}$ in $90.2 \%$ yield, which was treated with acetic anhydride in the presence of DMAP to afford 16 in $65.8 \%$ yield (Scheme 5 )

Pharmacology. For the evaluation of hepatoprotective 
activities, hepatotoxicity was artificially induced by administration of galactosamine or $\mathrm{CCl}_{4}$ into primary cultured rat hepatocytes. Prepared compounds were administered with different concentration. and relative glutanic pyruvic transaminase (GPT) activities were observed according to recovery of enzyme activities by Reitman-Frankel method. ${ }^{11}$ Hepatoprotective effect was indicated as \% value. (Normal GPT activity: $100 \%$. intoxicated GPT activity: $0 \%$ ). Hepatotoxicity induced by $\mathrm{CCl}_{4}$ was reported to be due to lipid peroxide which was trichloromethyl free radical $\left(\mathrm{CCl}_{3}\right)$ metabolite bound with intracellular proteins and lipids by the action of cytochrome P.450 dependent mixed oxidase. Hepatotoxicity induced by galactosamine has similarities with viral hepatitis in function and formation. Galactosanine was reported to inhibit RNA and protein synthesis. which was due to alteration of anount and metabolite of uracil nucleotides in liver. Galactosamine decreased the biosynthesis of biomacromolecules related to uracil nucleotides. such as UPP-glucuronic acid. which resulted in damage of related cells and cellular organelles.

Hepatoprotective activities of the prepared compounds were evaluated. Since silymarin has been reported to show potent antihepatotoxic effects and now widely used clinically in the treatment of many liver diseases or as hepatoprotectant. silymarin was utilized as a reference compound to compare hepatoprotective activities with the tested compounds. ${ }^{1 \hat{3}, 14}$ Silymarin was found to inhibit lipid peroxidation in rat liver nicrosomes and freshly isolated hepatocytes induced by pro-oxidant agents such as allyl alcohol and cumene hydroperoxide. ${ }^{15}$ Silymarin has a very potent hepatoprotective activity $(54.7 \%$ protection at $50 \mu \mathrm{M})$ against $\mathrm{CCl}_{+}$-induced hepatotoxicity, but does not show any activity against galactosamine(GaIN)-induced hepatotoxicity. Asiatic acid nearly does not have hepatoprotective activity against $\mathrm{CCl}_{4}$-induced hepatoxicity ( $1.0 \%$ protection at $50 \mu \mathrm{M})$. but moderate activity against $\mathrm{GaIN}$-induced hepatotoxicity $(23.1 \%$ protection at $50 \mu \mathrm{M})$.

Most of the tested compounds showed potent hepatoprotective activities. Especially compounds 9.13 and 16 showed significant hepatoprotective activity against both $\mathrm{CCl}_{4}-(20.7 \%$. $15.4 \%$ and $33.3 \%$ protection at $50 \mu \mathrm{M}$. respectively) and $\mathrm{GaNN}$-induced hepatotoxicity (66.4\%. $52.3 \%$ and $33.6 \%$ protection at $50 \mu \mathrm{M}$. respectively). In addition. compound 9 showed the most significant hepatoprotective effects against GaIN-induced hepatotoxicity' ( $66.4 \%$ protection at $50 \mu \mathrm{M}$ ) and moderate hepatoprotective activities against $\mathrm{CCl}_{+}$- induced hepatotoxicity $(20.7 \%$ protection at $50 \mu \mathrm{M}$ ) (Table 1).

Modification of hydroxy group into aldehyde group at C23 position (compound 9 and 13) dramatically increased the hepatoprotective effect ( $66.4 \%$ and $52.3 \%$. respectively) against $\mathrm{GaIN}$-induced hepatotoxicity. Modification of methoxy group of compound 11 which has no hepatoprotective effect. into benzy loxy group at $\mathrm{C} 2$ position (compound 16) increased the hepatoprotective effect $(33.3 \%$ and $33.6 \%$. respectively) against both $\mathrm{CCl}_{4}$ - and $\mathrm{GaIN}$-induced hepatotoxicity. It is interesting to note that simple modification of
Table 1. Hepatoprotective effects of the prepared compounds

\begin{tabular}{cccc}
\hline \multirow{2}{*}{ Compound } & $\mathrm{CCl}_{4}$-induced & & GalN-induced \\
\cline { 2 - 3 } & $\begin{array}{c}\text { Protection }(\%) \\
\text { at } 50 \mu \mathrm{M}\end{array}$ & & $\begin{array}{c}\text { Protection }(\%) \\
\text { at } 50 \mu \mathrm{M}\end{array}$ \\
\hline Asiatic acid $(1)$ & 1.0 & & 23.1 \\
$\mathbf{4}$ & 12.4 & 15.8 \\
9 & 20.7 & 66.4 \\
11 & $\mathrm{NE}$ & $\mathrm{NE}$ \\
$\mathbf{1 3}$ & 15.4 & 52.3 \\
$\mathbf{1 6}$ & 33.3 & 33.6 \\
Silymarin & 54.7 & $\mathrm{NE}$ \\
\hline
\end{tabular}

NE: not effective

methyl group on compound 11 to benzyl group at $\mathrm{C} 2$ position dramatically changed the hepatoprotective effect.

\section{Conclusions}

In conclusion. we prepared five asiatic acid derivatives by modification of $\mathrm{C} 2,3.23 .28$ functional groups on asiatic acid, and hepatoprotective effects of the prepared compounds were evaluated. Among them compounds 9.13 and 16 showed significant hepatoprotective activity against both $\mathrm{CCl}_{4}$ - and $\mathrm{GaIN}$-induced hepatotoxicity.

Acknowledgments. This work was supported by a grant (KRF-2006-005-J01101) from the Korea Research Foundation. R.O.K. The authors thank to Professors H.-g. Park and S.s. Jew in College of Pharmacy. Seoul National University for their valuable discussion and suggestions through this study.

\section{References}

1. Liu. J.; Liu. Y. P.; Klaassen. C. D. J. Ethanophamacol 1994. 12. 183.

2. Wang. B.: Jiang. Z. H. Chinese Phomacentical Jomal 1992. 27. 393.

3. Yabuchi. T.: Tanaka. T.: Sasatsuka. T.: Yamahara. T:: Fujimura. H. IP 1987,62126149.

4. Hikino, H: Ohsawa T; Kiso. Y: Oshima. Y. Planta Medica 1984. 50,353 .

5. Ma. X. H.: Zhao. Y. C.: Yin. L.: Han. D. W.: Want. M. S. Acta Pharnacentica Sinica 1986.21.332

6. Shukla. B.: Viser. S.: Patnaik. G. K.: Tripathi. S. C.: Srimal. R. C.: Day, S.: Dothal. P. C. Phytotherapy Res. 1992.6.74.

7. Sastri, B. N. In The Vealh of India, Raw Materials, C.S.I.R. New Delhi. 1950; vol. II, p 116

8. Jeong. B.-S.: Lee. M. K.: Kiml. Y. C.: Lee. E.-S. Awh Pham Res 2007. 30.282

9. Zhao. L.-X.: Park. H.g.: Jew S.-s.: Kim. M. K: Kim. Y. C.: Thapa. P.: Karki. R; Jahng, Y; Jeong, B.-S.: Lee, E.-S. Bull Korean Chem. Soc. 2007. accepted.

10. Berry, M. N.; Friend, D. S. J. of Cell Biol. 1984 +3, 506

11. Reitmant. S.: Frankel. S. A. Am. J. Clin. Pahol 1957. 28. 56.

12. Corey. E. J.: Ursprung. J. J. J. Am. Chem. Soc. 1956. 78. 183.

13. Vogel. G. In Natural Substances with Effects on the Liver: Springer Verlag: New York, 1977: p 249

14. Miguez. M: Anundi. I; Sainz-Pardo, L.: Lindros, K. O. Chem. Biol. Interact 1994. 91, 183 .

15. Daba. M. H.: Aldel-Rahman. M. S. Toxicol Lett. 1998. 95. 23. 